\title{
Sulphur Sources and Levels Differential Response on Yield, Storability and Economic Return of Onion (Allium cepa L.)
}

\author{
Dinisha Abhishek $^{1 *}$, Mahaveer Singh Bochalya ${ }^{2}$, Prashant Chauhan ${ }^{1}$, \\ Alok Shrivastava ${ }^{1}$ and Bagrawat Singh Dudi ${ }^{2}$ \\ ${ }^{1}$ Navsari Agriculture University, Bharuch-392012, India \\ ${ }^{2}$ Haryana Agriculture University, Hisar-125001, India \\ *Corresponding author
}

\section{A B S T R A C T}

\begin{tabular}{|l|}
\hline K e y w or d s \\
Gypsum, Nutrient uptake, \\
Onion, Quality, \\
Storability, Sulphur
\end{tabular}

The field trials were conducted during rabi season 2012-13 to 2014-15 at Vegetable Research Farm, CCS HAU, Hisar, India to evaluate the response of sulphur sources (gypsum and elemental sulphur) and doses $(0,15,30$ and $45 \mathrm{~kg} / \mathrm{ha})$ on yield, quality, storability as well as economic returns of onion (Allium cepa L., cv. 'Hisar Onion- 4'). Across different sulphur sources and levels, bulb yield increased by 7.02 to $16.66 \%$ as compared to those of the plants that received no sulphur. Application of gypsum at 30 $\mathrm{kg} / \mathrm{ha}$ resulted in the highest bulb yield (245.34 q/ha), benefit cost ratio (2.43) and relatively lesser physiological loss of weight $(20.34 \%)$, rotting $(8.32 \%)$ and sprouting (15.24\%), but was not significantly different with sulphur applied at $45 \mathrm{~kg} / \mathrm{ha}$. The maximum uptake of nitrogen, phosphorus, potassium and sulphur was also observed in bulbs treated with $30 \mathrm{~kg}$ gypsum/ha. Sulphur in the form of gypsum at $30 \mathrm{~kg} / \mathrm{ha}$ may be recommended for better nutritional status and economic return of onion crop under sandy loam soil conditions.

\section{Introduction}

Onion a high value crop is used as vegetable and spice all over the world. In India, onion is predominantly cultivated during rabi followed by kharif and late kharif season.

India ranks next to China in area and production of onion and fetches good foreign exchange among the various vegetable crops grown. However, the productivity of onion is 14 tones/ha in the country as compared to 4060t/ha are found in Korea, Japan, Europe and the USA (http://www.yara.in/crop-nutrition/ crops/onion-and-garlic/key-facts/world-onion - production/).

Onion is a sulphur loving plant and is required for proper vegetative growth and bulb development (Jana and Kabir, 1990). The levels of sulphur in growth media not only affects yield but quality components like Total soluble solids (TSS), pungency and flavors are influenced by sulphur spatial variability (Jaggi and Dixit, 1999). Sulphur interacts closely with other nutrients and a low sulphur level in growth media induces poor absorption of nitrogen $(\mathrm{N})$, phosphorus 
$(\mathrm{P})$, potassium $(\mathrm{K})$ and sulphur $(\mathrm{S})$ by plant roots (Nasreen et al., 2007). Storage of onion, essential to fulfill offseason demand, export and processing is a serious problem in India. Sulphur application increased the shelf life of onion (Thangasamy et al., 2013).

The objective of our study was to evaluate the response of sulphur application on onion bulb yield, quality attributes and storability in order to optimize perfect dose of two forms of sulphur

\section{Materials and Methods}

The field experiments were conducted for three consecutive rabi seasons of 2012-13 to 2014-15 at Vegetable Research Farm, Chaudhary Charan Singh Haryana Agricultural University (CCS HAU), Hisar $\left(29^{\circ} 09^{\prime} \mathrm{N}, 7^{\circ} 42^{\prime} \mathrm{E}\right.$ and $\left.215 \mathrm{~m}\right)$, under All India Network Research Project on Onion and Garlic. The soil of the experimental area was sandy loam in texture, having $\mathrm{pH}$ around 8.0; available N-P-K and S were 180, 19.60, 192.5 and $22.50 \mathrm{~kg} / \mathrm{ha}$, respectively with $0.24 \%$ organic carbon. Two sources of sulphur (gypsum and elemental sulphur) at four levels $(0,15,30$ and $45 \mathrm{~kg} / \mathrm{ha})$ were used as experimental variables each year. The experiment was laid out in a randomized block design (RBD) under factorial arrangement with three replications. The seven weeks old healthy seedlings of test variety 'Hisar Onion-4' were transplanted at a spacing of $15 \times 10 \mathrm{~cm}^{2}$, in all the years. The recommended dose of $\mathrm{P}, \mathrm{K}$ and half dose of $\mathrm{N}$ was applied at the time of land preparation while the remaining $\mathrm{N}$ was top dressed at 30 days after transplanting. Sulphur in the form of gypsum (Gy) was applied as basal dose and elemental sulphur (ES) was top dressed at 30 days after transplanting. Recommended package of practices were adopted to raise healthy onion crop in all the experimental seasons.
The crop was harvested after maturity, each year in the first week of May. The bulb samples from each treatment were collected randomly to record data. Total soluble solids were determined using the refractometer. To determine dry matter accumulation bulb samples were oven dried at $70^{\circ} \mathrm{C}$ until a constant weight was attained. Nitrogen content from the dry bulbs was determined by modified Kjeldahl digestion method whereas, for the determination of $\mathrm{P}, \mathrm{K}$ and $\mathrm{S}$ bulb samples were digested in a di-acid mixture $\left(\mathrm{HNO}_{3}\right.$ and $\left.\mathrm{HClO}_{4}\right)$ and from the extract $\mathrm{P}, \mathrm{K}$ and $\mathrm{S}$ content was determined by vanadomolybdate yellow colour method, flame photometer and turbidi metric method, respectively. Nutrients uptake was estimated by multiplying dry matter data with the values obtained from the above respective methods for $\mathrm{N}, \mathrm{P}, \mathrm{K}$ and $\mathrm{S}$ contents (\%). Moreover, five kilogram bulbs collected from each plot were stored in bamboo rack to study the effect of sulphur on onion shelf life, after four months of storage.

The data recorded on different parameters were statistically analyzed to obtain the level of significance using the online statistical software OPSTAT provided by the University (www.hau.ernet.in/opstat.html).

\section{Results and Discussion}

\section{Effect of sulphur on growth, yield and its attributes}

Three years pooled data on vegetative growth yield and quality attributes of onion bulb as influenced by different sources and levels of sulphur showed significant variation (Table 1). Application of sulphur significantly increased the onion plant height and number of leaves. Sulphur at $30 \mathrm{~kg} / \mathrm{ha}$ irrespective of the source, recorded maximum vegetative growth. However, Gy recorded higher plant height $(55.34 \mathrm{~cm})$ and number of leaves (14.67) than ES $(54.68 \mathrm{~cm}$ and 14.34 , 
respectively). Between two different sources of sulphur no noticeable difference was observed for both the traits. The increase in vegetative growth might be ascribed to decrease in soil $\mathrm{pH}$ due to sulphur application which in turn activated the absorption of $\mathrm{N}, \mathrm{P}$, $\mathrm{K}$ and $\mathrm{S}$ from the rhizosphere (Figure 2).

Sulphur fertilization significantly influenced the yield and yield attributing characters regardless of the sources and levels over control, except for doubles and bolters. Across different sulphur doses, bulb yield increased by 7.02 to $16.66 \%$ over control (Figure 1). Plants treated with Gy at $30 \mathrm{~kg} / \mathrm{ha}$ registered highest bulb yield (245.34 q/ha), bulb weight $(61.26 \mathrm{~g})$ and benefit cost ratio \{B: C ratio\} (2.43).

The yield and $\mathrm{B}$ : $\mathrm{C}$ ratio was lowest in control plants $(210.32 \mathrm{q} / \mathrm{ha}$ and 1.80 , respectively) with no sulphur application and was statistically different from other treatments. Increasing the sulphur dose from 30 to 45 $\mathrm{kg} / \mathrm{ha}$ slightly increased the bulb yield during 2011-12 and 2012-13 whereas, reduction in yield of 9.14 and $4.75 \%$ was observed in plants treated with Gy and ES, respectively during 2013-14 (data not shown). Significant increase in the bulb yield was found from the plants treated with $30 \mathrm{~kg} \mathrm{~S} / \mathrm{ha}$, irrespective of the sources and years.

The highest equatorial and polar diameter (5.60 and $5.52 \mathrm{~cm}$, respectively) was also recorded with the application of $30 \mathrm{~kg}$ Gy $/ \mathrm{ha}$. However, response of Gy at 45 and ES at 30 $\mathrm{kg} / \mathrm{ha}$ were found statistically identical. Bolting and doubles percentage were not significantly affected by the sources and levels of sulphur. Although, highest numbers of split bulbs $(0.30 \%)$ and bolters $(2.97 \%)$ were counted in treatment applied with ES at $45 \mathrm{~kg} / \mathrm{ha}$ and lowest values $(0.07$ and $1.24 \%$, respectively) in control (Table 1). Averaged over experimental years, the study revealed that increase in sulphur level beyond $30 \mathrm{~kg} / \mathrm{ha}$ negatively affected the onion bulb yield and concomitant traits. This might have been due to imbalance caused by higher sulphur level in the rhizosphere which resulted in poor absorption of nutrients and finally lead to poor yield. Tripathy et al., (2016) observed significant increase in onion bulb yield with the application of Gy at $30 \mathrm{~kg} / \mathrm{ha}$.

Table.1 Three years (2012-13, 2013-14 \& 2014-15) pooled data on growth, yield, quality and economic returns of onion as affected by different sources and doses of sulphur

\begin{tabular}{|c|c|c|c|c|c|c|c|c|c|c|}
\hline Treatment & $\begin{array}{c}\text { Plant } \\
\text { height } \\
(\mathbf{c m})\end{array}$ & $\begin{array}{l}\text { No. of } \\
\text { leaves } \\
\text { plant }^{-1}\end{array}$ & $\begin{array}{c}\text { Equatorial } \\
\text { diameter } \\
\text { (cm) }\end{array}$ & $\begin{array}{c}\text { Polar } \\
\text { diameter } \\
(\mathbf{c m})\end{array}$ & $\begin{array}{l}\text { Bulb } \\
\text { Weight } \\
\text { (g) }\end{array}$ & $\begin{array}{c}\text { Bolters } \\
(\%)\end{array}$ & $\begin{array}{c}\text { Doubles } \\
(\%)\end{array}$ & $\begin{array}{c}\text { Bulb } \\
\text { yield } \\
\text { (q/ha) }\end{array}$ & $\begin{array}{c}\text { TSS }^{\mathrm{a}} \\
\left({ }^{\circ} \mathrm{Brix}\right)\end{array}$ & $B: C^{b}$ \\
\hline Control & 48.34 & 10.67 & 4.69 & 4.67 & 49.90 & 1.24 & 0.07 & 210.32 & 9.88 & 1.80 \\
\hline${ }^{1}$ Gy 15 & 53.30 & 13.34 & 5.22 & 5.12 & 53.51 & 2.34 & 0.11 & 228.12 & 10.48 & 2.10 \\
\hline Gy 30 & 55.34 & 14.67 & 5.60 & 5.42 & 61.46 & 2.60 & 0.16 & 245.34 & 11.53 & 2.43 \\
\hline Gy 45 & 54.30 & 13.67 & 5.48 & 5.22 & 58.20 & 2.82 & 0.24 & 240.67 & 10.90 & 2.39 \\
\hline${ }^{2}$ ES 15 & 53.65 & 12.34 & 4.92 & 4.90 & 52.45 & 2.30 & 0.13 & 225.10 & 10.30 & 2.06 \\
\hline ES 30 & 54.68 & 14.34 & 5.40 & 5.32 & 59.56 & 2.97 & 0.21 & 239.90 & 11.42 & 2.36 \\
\hline ES 45 & 53.92 & 14.00 & 5.30 & 5.17 & 58.40 & 2.93 & 0.30 & 235.60 & 11.18 & 2.33 \\
\hline Mean & 53.36 & 13.29 & 5.23 & 5.12 & 56.21 & 2.46 & 0.16 & 232.15 & 10.81 & 2.21 \\
\hline $\begin{array}{c}\text { CD } \\
(p=0.05)\end{array}$ & 3.45 & 1.02 & 0.58 & 0.49 & 8.10 & NS & NS & 29.20 & 1.28 & 0.10 \\
\hline $\begin{array}{c}\text { CD } \\
3(S \times L) \\
(p=0.05)\end{array}$ & NS & NS & NS & NS & NS & NS & NS & 38.10 & NS & NS \\
\hline
\end{tabular}

${ }^{1}$ Gy- Gypsum; ${ }^{2}$ ES- Elemental sulphur; ${ }^{3} \mathrm{~S} \times$ L- Sources $\times$ Levels; ${ }^{a}$ TSS: Total soluble solids; ${ }^{b} \mathrm{~B}: \mathrm{C}$ - Benefit cost ratio 
Table. 2 Three years pooled data on shelf life of onion as affected by different sources and doses of sulphur

\begin{tabular}{|l|c|c|c|}
\hline Treatment & $\begin{array}{c}\text { PLW } \\
(\mathbf{\%})\end{array}$ & $\begin{array}{c}\text { Sprouting } \\
(\mathbf{\%})\end{array}$ & $\begin{array}{c}\text { Rotting } \\
(\mathbf{\%})\end{array}$ \\
\hline Control & 32.34 & 22.76 & 17.78 \\
\hline Gy 15 & 28.00 & 19.04 & 12.07 \\
\hline Gy 30 & 20.34 & 15.24 & 8.32 \\
\hline Gy 45 & 23.50 & 17.10 & 13.56 \\
\hline ES 15 & 29.82 & 17.20 & 12.13 \\
\hline ES 30 & 22.10 & 16.18 & 9.67 \\
\hline ES 45 & 23.26 & 18.24 & 14.24 \\
\hline Mean & 25.62 & 17.97 & 12.54 \\
\hline CD (p=0.05) & NS & NS & NS \\
\hline $\begin{array}{l}\text { CD }(\boldsymbol{p = 0 . 0 5 )} \\
\text { (S X L) }\end{array}$ & NS & NS & NS \\
\hline
\end{tabular}

${ }^{1}$ Gy- Gypsum; ${ }^{2}$ ES- Elemental sulphur; ${ }^{3}$ S $\times$ L- Sources $\times$ Levels; PLW- Physiological weight loss

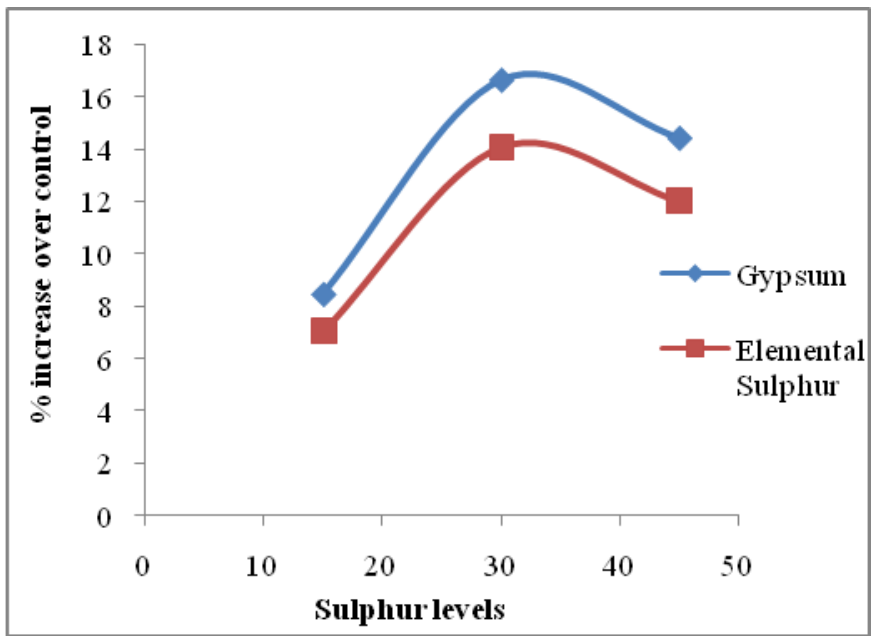

Figure.1 Effect of sulphur sources and levels on yield and attributing traits over control (no sulphur added).

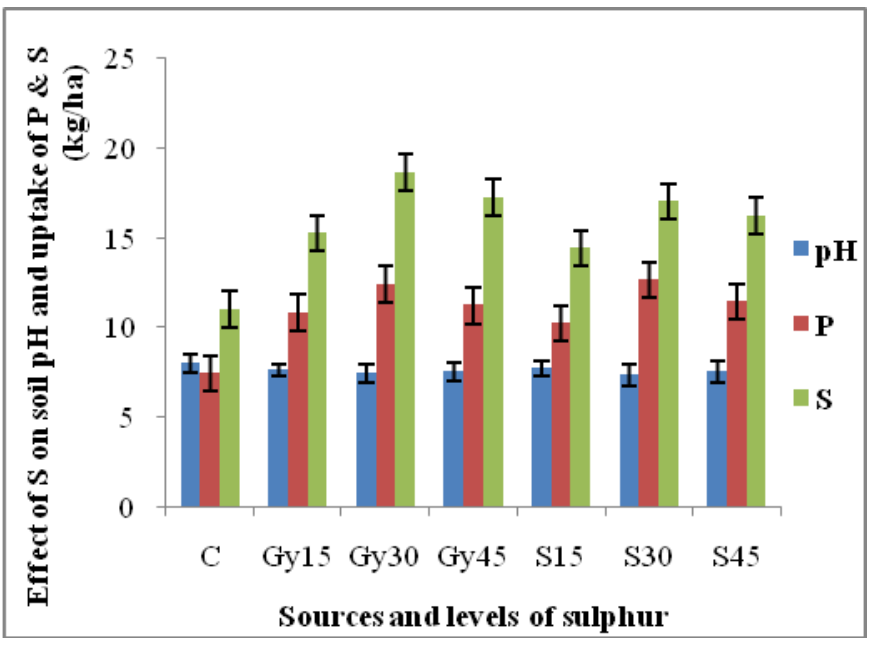

Figure.2 Effect of sources and levels of sulphur on soil $\mathrm{pH}$ and uptake of and uptake of phosphorus and sulphur in onion bulbs (average of three years) The vertical bars indicate standard deviation. 


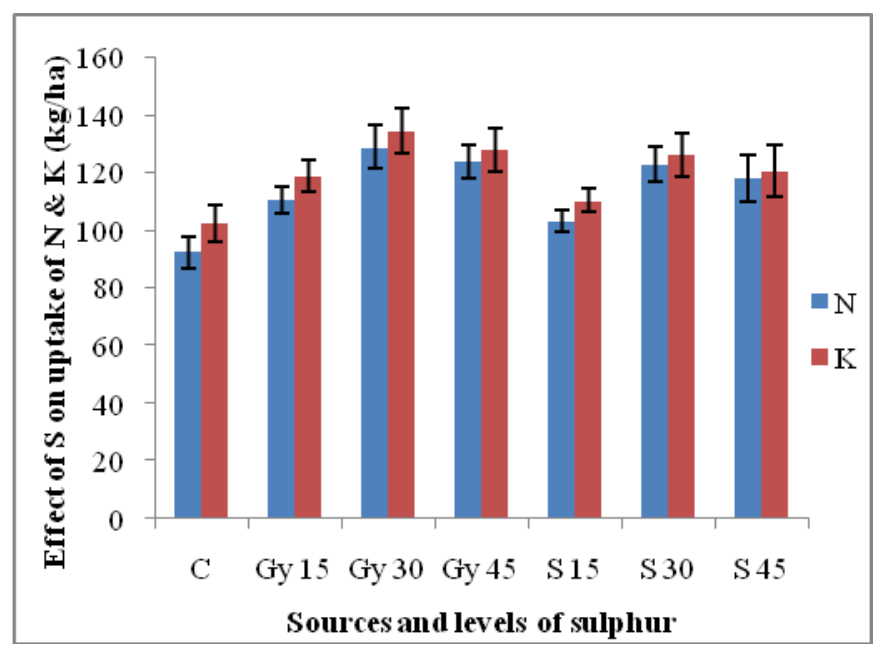

Figure.3 Effect of sources and levels of sulphur on uptake of nitrogen and potassium in onion bulbs (avg. of three years)

In contrast, Bharti and Ram (2014) showed that ES at $40 \mathrm{~kg} / \mathrm{ha}$ significantly enhanced yield in onion. The interaction effect over the years was not significant for any of the traits except total bulb yield.

\section{Effect of sulphur on soil pH, quality, storability and uptake of nutrients}

During the experimental years $\mathrm{pH}$ of the onion rhizosphere decreased in all the treatments (Figure 2), however, maximum decline of $\mathrm{pH}$ was found in $\mathrm{Gy}$ at $30 \mathrm{~kg} / \mathrm{ha}$ (7.4) over control (8.0). The release of $\mathrm{H}^{+}$ ions during sulphur oxidation might have resulted in decrease $\mathrm{pH}$ values. Awad et al., (2011) also observed decrease in soil pH with inoculation of sulphur oxidizing bacteria. Decrease in soil $\mathrm{pH}$ is essential to improve the nutrients uptake by plant roots in calcareous soil with high $\mathrm{pH}$ values.

Significantly higher TSS was observed in onion bulbs treated with Gy and ES at $30 \mathrm{~kg} / \mathrm{ha}(11.53$ and $11.42^{\circ}$ Brix, respectively) over control $\left(9.86^{\circ}\right.$ Brix), whereas it was at par with application of $45 \mathrm{~kg} \mathrm{ES} / \mathrm{ha}$ (Table 1). Onion storage data revealed no significant effect of different sources and levels of sulphur on bulb shelf life. However, in comparison to control, the least physiological loss of weight (PLW), rotting and sprouting (20.34, 8.32 and $15.24 \%$, respectively) was found with application of Gy at $30 \mathrm{~kg} / \mathrm{ha}$ (Table 2). These findings support results of Tripathy et al., (2013).

Uptake of nutrients by onion bulbs increased significantly with increasing level of sulphur upto $30 \mathrm{~kg} / \mathrm{ha}$, irrespective of the sources. The mean concentration of $\mathrm{N}, \mathrm{P}, \mathrm{K}$ and $\mathrm{S}$ increased to $39.35,67.57,31.45$ and $69.09 \%$, respectively at $30 \mathrm{~kg} \mathrm{~Gy} / \mathrm{ha}$ in comparison to control.

Although no observable difference was observed in response of both forms of sulphur sources at 30 and $45 \mathrm{~kg} / \mathrm{ha}$ (Figure 2 and 3 ). Application of sulphur in soil improves the use efficiency of N, P and K (Nasreen et al., 2007).

The trend follows the yield trend and thus, might be attributed to higher yield. The increase in uptake of $\mathrm{N}, \mathrm{P}, \mathrm{K}$ and $\mathrm{S}$ was also reported by Sankaran et al., (2005) at $45 \mathrm{~kg}$ S/ha while Dabhi et al., (2004) was obtained from $30 \mathrm{~kg}$ S/ha.

The results of three year experiments clearly reflect the favorable effect of sulphur on onion crop. Application of gypsum at $30 \mathrm{~kg} / \mathrm{ha}$ along with recommended doses of $\mathrm{N}, \mathrm{P}$ and $\mathrm{K}$ can help to improve yield, nutritional status, shelf life and net economic return of onion crop under sandy loam soil with high $\mathrm{pH}$. 


\section{Acknowledgement}

Funding support from Directorate of Onion and Garlic, Pune under All India Network Research Project on Onion and Garlic (ICAR) is highly acknowledged.

\section{References}

Awad, N.M., Abd, El-Kader., A.A., Attia, M., and Alva, A.K. 2011. Effects of nitrogen fertilization and soil inoculation of sulfuroxidizing or nitrogen-fixing Bacteria on onion plant growth and yield. Int J Agro. http://dx.doi.org/10.1155/2011/316856.

Bharti, N., Ram, R.B. 2014. Estimating variation in the production, quality and economics of onion in response to transplanting dates and sulphur fertilization. Euro Acad Res. 2(4): 48314843.

Dabhi, N.M., Patel, M.V., and Patel, V.R. 2004. Effect of sources and levels of sulphur on yield and chemical composition of onion in loamy sand. National Seminar on Development in Soil Science: 69th Annual Convention, Hyderabad, India. p. 124.
Jaggi, R.C., and Dixit, S.P. 1999. Onion (Allium Cepa L.) response to sulphur in representative vegetable growing soils of Kangra Valley of Himachal Pradesh. Ind J Agril Sci. 69: 289-291.

Jana, B.K., and Kabir, J. 1990. Effect of sulphur on growth and yield of onion cultivar Nasik red. Crop Res. 3(2): 241-243.

Nasreen, S., Haque, M.M., Hossain, M.A., and Farid, A.T.M. 2007. Nutrient uptake and yield of onion as influenced by nitrogen and sulphur fertilization. Banglad J Agril Res. 32(3): 413-420.

Sankaran, K., Bharathi, C. and Sujatha, S. 2005. Effect of sulphur fertilization on yield and nutrient uptake by onion in red soil (Uodic Haplustalf). J Mahar Agril Univ. 30 (2): 135-136.

Thangasamy, A., Sankar, V., Lawande, K.E. 2013. Effect of sulphur nutrition on pungency and storage life of short day onion (Allium cepa). Ind J Agril Sci. 83(10): 1086-1089.

Tripathy, P., Sahoo, B.B., Patel, D., and Dash, D.K. 2016. Efficacy of sulphur on growth, yield and bulb quality in onion (Allium cepa L.). J Spices Aromt. Crops 25(1): 60-64.

\section{How to cite this article:}

Dinisha Abhishek, Mahaveer Singh Bochalya, Prashant Chauhan, Alok Shrivastava and Bagrawat Singh Dudi. 2018. Sulphur Sources and Levels Differential Response on Yield, Storability and Economic Return of Onion (Allium cepa L.). Int.J.Curr.Microbiol.App.Sci. 7(06): 866-871. doi: https://doi.org/10.20546/ijcmas.2018.706.101 